\title{
PERLINDUNGAN HUKUM BAGI BANK SEBAGAI PEMEGANG JAMINAN HAK ATAS TANAH DAN BANGUNAN MILIK DEBITUR YANG DISITA OLEH KOMISI PEMBERANTASAN KORUPSI (KPK)
}

\section{LEGAL PROTECTION FOR THE BANK AS THE GUARANTEE HOLDER OF RIGHTS TO LAND AND BUILDINGS WHICH WAS CONFISCATED BY CORRUPTION ERADICATION COMMISSION}

Abraarsyah*, Sukarmi

Program Studi Magister Kenotariatan Pascasarjana Fakultas Hukum Universitas Brawijaya Jalan MT. Haryono Nomor 169, Malang 65145 Indonesia

\section{INFO ARTIKEL}

\section{Riwayat Artikel:}

Diterima : 09 Desember 2019

Disetujui : 29 Desember 2020

\section{Keywords:}

Legal Protection, Land and Building owned, Corruption Eradication Commission (KPK), Confiscation

\section{Kata Kunci:}

Perlindungan Hukum, Jaminan Hak Atas Tanah dan Bangunan, Komisi Pemberantasan Korupsi, Penyitaan

\section{*) Korespondensi:}

E-mail: abraarsyahazis@ gmail.com

\begin{abstract}
Abstarct: this study aimed to analyze legal protection for banks as holders of legal guarantees for land and buildings owned by debtors that were confiscated by the Corruption Eradication Commission (KPK). The research used juridical-normative type. The research used statute approach, conceptual approach, and case approach. This study used domain analysis techniques. The results showed that if the KPK confiscated the land and / or buildings of the debtor owner, the Bank, as the holder of the guarantee of the rights to the land and buildings, would receive legal protection both preventively and repressively.
\end{abstract}

\begin{abstract}
Abstrak: penelitian ini bertujuan untuk mengetahui dan menganalisis perlindungan hukum bagi bank sebagai pemegang jaminan hak atas tanah dan bangunan milik debitur yang disita oleh Komisi Pemberantasan Korupsi (KPK). Jenis penelitian yang digunakan dalam penelitian ini adalah yuridis normatif. Pendekatan yang digunakan adalah pendekatan perundangundangan (statute approach), pendekatan konseptual (conceptual approach) dan pendekatan kasus (case approach). Penelitian ini menggunakan teknik analisis domain. Hasil penelitian menunjukkan bahwa apabila KPK menyita tanah dan/atau bangunan pemilik debitur, Bank sebagai pemegang jaminan hak atas tanah dan bangunan mendapatkan perlindungan hukum baik secara preventif maupun represif.
\end{abstract}

\section{PENDAHULUAN}

Tanah dan bangunan yang berada di atasnya merupakan bagian dari harta kekayaan seseorang yang memiliki nilai ekonomi yang cukup menjanjikan bagi kehidupan seseorang atau suatu keluarga. Karenanya dalam kepemilikannya seseorang harus dapat membuktikan bahwa tanah dan bangunan diatasnya, adalah miliknya dengan sertifikat (arifuddin, Widhiyanti \& Susilo, 2017). Sehingga ia dapat dikatakan sebagai pemilik yang sah.

Salah satu fungsi dari bukti kepemilikan tersebut adalah pemegang hak dapat mengajukan pinjaman atas kepemilikan tersebut pada bank. Bank sebagai lembaga keuangan akan mengabulkan permohonan pengajuan pinjaman seseorang ketika telah memenuhi syarat yang ditentukan oleh bank (Choiriyah, 2019). Sebagaimana diamanatkan dalam UU Nomor 10 Tahun 1998 tentang Perbankan.

Bank wajib memiliki dan menjalankan dengan baik pedoman tentang perkreditan sebagaimana telah tertulis pada Pasal 8 ayat 2 yang diatur lebih lebih lanjut dengan SK Direksi BI No 27/ 162/ KEP/ DIR. Semua Bank umum diharuskan untuk mempunyai dan menjalankan Kebijaksanaan Perkreditan Bank (KPB) dalam pelaksanaan kegiatan proses perkreditannya dan selain itu melampirkan Pedoman Penyusunan Kebijaksanaan Perkreditan Bank (PPKPB).

Seluruh prinsip-prinsip yang harus dipenuhi dan dilaksanakan oleh Bank sebelum menyetujui dan mencairkan fasilitas kredit maupun fasilitas pembiayaan dalam prinsip syariah penting untuk 
mencegah terjadinya kredit yang kurang lancar apalagi kredit tersebut dinyatakan macet (lih. PBI No. 7/ 2/ PBI/ 2005). Oleh sebab itu bank dalam prosesnya dalam melaksanakan perjanjian pengikatan jaminan atau perjanjian ikutan sebagai penerapan prinsip 5C salah satunya ialah agunan atau jaminan (Kasmir, 2002). Maka Bank dalam menyetujui dan mencairkan fasilitas pemberian kredit dan diikat dengan suatu jaminan utang, terutama jaminan hak tanggungan yang biasa objeknya adalah tanah.

Namun dalam kenyataan, tanah dan bangunan yang dimiliki oleh seorang debitur atau seorang penjamin tidaklah selalu dibeli dengan uang yang diperoleh secara hukum. Terkadang guna menyamarkan hasil korupsi seorang pelaku menginvestasikan dalam bentuk tanah dan bangunan atau berbagai jenis investasi lainnya dengan mengalihkan kepemilikan kepada keluarga terdekat sehingga ketika membutuhkan dana besar maka mereka akan dengan mudah memperolehnya (Rahmi \& Sjafi'i, 1991).

Apabila perbuatan tersebut diungkap oleh KPK, maka harta tersebut akan menerima dampak karena KPK akan melakukan penyitaan terhadap harta yang dinyatakan dalam putusan pengadilan termasuk terhadap harta kekayaan yang telah dijadikan jaminan utang pada bank. Penyitaan menjadi awal tahapan proses perkara korupsi dari tingkat penyelidikan, penyidikan, penuntutan dan sidang di pengadilan (Rosyad, 2014). Prinsip kehati-hatian perlu digunakan dalam menyita barang atau benda yang digunakan dalam suatu perkara pidana. Harus dipastikan bahwa antara benda yang disita dengan pelaku tindak pidana itu ada korelasinya yang betulbetul akurat (Suhartati, 2014). Karena apabila penyidik tidak dapat menjelaskan hubungan dari barang yang akan disita dengan suatu tindak pidana yang disangkakan maka izin penyitaan dapat ditolak oleh Ketua Pengadilan Negeri setempat (Rosyad, 2014). Harta sitaan inilah yang kelak diputuskan oleh pengadilan, apakah harus diambil sebagai upaya untuk pengembalian kerugian keuangan negara atau sebagai pidana tambahan berupa merampas hasil kejahatan.

Hal tersebut akan menjadi kendala ketika barang yang akan disita oleh KPK tersebut telah menjadi jaminan atas suatu utang. Karena barang tersebut menjadi jaminan yang diberikan oleh debitur akan pelunasan utangnya dan menjadi jaminan bagi bank bahwa utang debitur tersebut akan dilunasi, sebagaimana ditentukan dalam Pasal 1131 KUHPer.

Terhadap jaminan tanah dan bangunan di atasnya, bank akan langsung mengikat dengan perjanjian hak tanggungan atau penandatangan Akta Pemberian Hak Tanggungan (APHT). Disamping itu sebagai perjanjian accesoir, yakni perjanjian ada karena adanya perjanjian pokok, maka penyitaan terhadap barang jaminan akan mempengaruhi penyelesaian pinjaman debitur pada bank tersebut. Hal ini dipengaruhi apakah terhadap jaminan tersebut dalam proses pemasangan hak tanggungannya telah selesai atau belum.

Pemasangan hak tanggungan tidak cukup hanya sampai telah dilakukannya perjanjian pembebanan hak tanggungan, tetapi perjanjian tersebut harus didaftarkan pada kantor pertanahan untuk dicantumkan pada sertifikatnya bahwa terhadap tanah beserta bangunan telah dipasang hak tanggungan (Valayvi, 2016). Hal ini disebutkan dalam UUHT No.4 tahun 1996 pasal 13 ayat (1), yakni pemberian Hak Tanggungan wajib didaftarkan pada kantor pertanahan (Valayvi, 2016).

Dilihat dari pasal 1 ayat (1) UUHT No.4 tahun 1996 yang dimaksud Hak Tanggungan adalah hak jaminan yang dibebankan pada hak atas tanah sebagaimana dimaksud dalam UUPA No.5 tahun 1960, berikut atau tidak berikut benda - benda lain yang menjadi satu kesatuan dengan tanah tersebut, untuk pelunasan utang tertentu, yang memberikan kedudukan yang diutamakan kepada kreditur tertentu terhadap kreditur - kreditur lain. Karena memberikan kedudukan yang diutamakan tersebut hal ini akan menyebabkan terjadinya konflik norma jika jaminan hak atas tanah tersebut disita oleh KPK. Dimana jika dilihat pada pasal 47 ayat (1) UU No.30 tahun 2002 tentang KPK menyebutkan atas dasar dugaan yang kuat adanya bukti permulaan yang cukup penyidik dapat melakukan penyitaan tanpa izin ketua pengadilan negeri berkaitan dengan tugas penyidikannya.

Apabila dilihat dari maksud di atas, maka penyitaan barang jaminan berupa hak atas tanah milik debitur oleh KPK, bisa menyebabkan bank bukan lagi sebagai kreditur yang diutamakan (preference) atas pelunasan hutang debitur, 
apalagi jika proses pemasangan hak tanggungan belum selesai. Penyitaan akan ada masalah ketika debitur tidak dapat mengganti jaminannya yang telah disita KPK sebesar nilai utang yang tersisa. Permasalahan yang dimungkinkan timbul adalah ketika proses penyitaan itu sendiri tidak memiliki kepastian jangka waktu sampai kapan penyitaan itu dilakukan, hingga sampai adanya putusan hakim yang berkekuatan hukum tetap atas perkara tindak pidana korupsi tersebut. Masalah ini akan menimbulkan kerugian yang tidak sedikit bagi bank. Karenanya perlu adanya solusi yang baik, terkait disitanya barang jaminan utang oleh KPK.

Adapun tujuan dari penelitian ini adalah untuk mengetahui dan menganalisis kedudukan jaminan hak atas tanah dan bangunan milik debitur yang disita oleh KPK terhadap pelunasan utang baik yang sudah terpasang Hak Tanggungan maupun yang belum terpasang. Lalu Untuk mengetahui dan menganalisis bentuk perlindungan hukum bagi bank terhadap jaminan berupa hak atas tanah dan bangunan milik debitur yang disita oleh KPK, dalam pelunasan utang.

\section{METODE PENELITIAN}

Jenis penelitian dalam penelitian ini adalah yuridis normatif, penelitian hukum kepustakaan terhadap hukum normatif yang berlaku. Penelitian ini didasarkan pada kaidah-kaidah hukum yang berlaku serta dikaitkan dengan tindakan (act) subyek hukum tersebut sesuai dengan norma hukum atau prinsip hukum (Marzuki, 2011). Penelitian ini meneliti bahan hukum berkaitan dengan kedudukan jaminan hak atas tanah dan bangunan milik debitur sebagai jaminan utang, yang disita oleh KPK.

Spesifikasi penelitian yang digunakan adalah deskritif analisis, yang memberi gambaran secara komprehensif tentang kaidah-kaidah hukum yang berkaitan dengan jaminan dan penyitaan jaminan bank oleh KPK, dan teori-teori hukum yang mendukung dalam menganalisa permasalahan yang muncul dalam praktik.

Pendekatan yang digunakan dalam penelitian ini adalah pendekatan perundang-undangan (statute approach), pendekatan konseptual (conceptual approach) dan pendekatan kasus (case approach). Sumber bahan hukum yang digunakan berupa bahan hukum primer dan bahan hukum sekunder. Pengolahan bahan hukum dilakukan dengan secara analisis kualitatif domain artinya menarik suatu kesimpulan permasalahan yang bersifat umum.

\section{HASIL DAN PEMBAHASAN}

\section{Kedudukan Jaminan Hak Atas Tanah dan Bangunan Milik Debitur Yang Disita Oleh KPK}

Menurut Pasal 12 huruf i UU KPK dalam melaksanakan tugas penyelidikan, penyidikan dan penuntutan. KPK diberi kewenangan oleh undang-undang, salah satunya adalah meminta bantuan kepolisian atau instansi lain yang terkait untuk penangkapan, penahanan, penggeledahan, dan penyitaan dalam perkara tindak pidana korupsi yang sedang ditangani (Abdullah, 2014). Hal ini dimaksudkan agar orang yang diduga telah melakukan tindak pidana korupsi, tidak melarikan diri atau tidak mengalihkan hartanya kepada pihak lain, sehingga dapat dijadikan barang bukti dalam persidangan (Tatuil, 2013). Dan karenanya berdasarkan Pasal 47 ayat (1) UU KPK, maka sebagai penyidik dan berkaitan dengan tugasnya tersebut, KPK dapat melakukan salah satunya penyitaan tanpa izin Ketua Pengadilan, atas dasar adanya dugaan yang kuat dan adanya bukti permulaan yang cukup.

Akan tetapi penyitaan dapat termasuk dalam salah satu upaya paksa (dwang middelen) yang dapat melanggar hak asasi manusia. Maka sesuai ketentuan Pasal 38 KUHAP, penyitaan hanya dapat dilakukan oleh penyidik dengan izin dari Ketua Pengadilan Negeri setempat. Dalam keadaan tertentu penyitaan dapat dilakukan terlebih dahulu kemudian dilaporkan ke Ketua Pengadilan Negeri untuk memperoleh persetujuan.

Pembebanan jaminan tanah dan bangunan dimaksudkan untuk memberikan kepada kreditur kedudukan yang diutamakan atau sebagai kreditur preferen, dan untuk memperoleh kedudukan tersebut maka pasal 13 UUHT pemberian hak tanggungan tersebut harus segera didaftarkan pada Kantor Pertanahan selambat-lambatnya tujuh hari kerja setelah penanda-tanganan APHT. Sebagai pemegang Hak Tanggungan pertama maka hak ini tetap mengikuti objeknya dimana objek itu berada atau objek tersebut berada ditangan pihak lain (droit de suite) (Wiraatmaja, Silviana, \& Sukirno, 2016).

Sekalipun memiliki hak tagih yang diutamakan terhadap hak tagihan krediturkreditur lain, namun terhadap piutang-piutang 
Negara tidaklah demikian. Piutang-piutang Negara lebih didahulukan dari kreditur pemegang hak jaminan tanah dan bangunan yang ada di atasnya (kreditur preferen). Sebagaimana dimaksud dalam Pasal 1137 BW adalah Hak dari Kas Negara, Kantor Lelang dan lain-lain Badan Umum yang dibentuk oleh Pemerintah.

Jadi apabila tidak ditentukan bahwa suatu piutang merupakan hak istimewa yang memiliki kedudukan lebih tinggi dari pada piutang yang dijamin dengan suatu hak jaminan tanah dan bangunan yang ada diatasnya (gadai, fidusia, hak tanggungan atau hipotek) maka urutan kreditur sebagai berikut: (1) Kreditur yang memiliki piutang yang dijamin dengan hak jaminan tanah dan bangunan yang ada diatasnya (kreditur preference); (2) Kreditur yang memiliki hak istimewa (kreditur separatis); (3) Kreditur konkuren.

Apabila suatu hak istimewa ditentukan harus dilunasi terlebih dahulu dari pada kreditur pemegang hak jaminan tanah dan bangunan yang ada diatasnya, maka urutan kreditur sebagai berikut: (1) kreditur yang memiliki hak istimewa; (2) kreditur yang memiliki piutang yang dijamin dengan hak jaminan tanah dan bangunan yang ada diatasnya; (3) kreditur konkuren.

Piutang-piutang terhadap kas negara, memiliki hak untuk didahulukan dalam pelunasannya ketimbang kreditur yang piutangnya dijamin dengan hak jaminan tanah dan bangunan yang ada di atasnya. Dan bila harta kekayaan debitur yang disita oleh KPK karena diduga dan / atau terbukti sebagai hasil tindak pidana korupsi dan harus dikembalikan karena merupakan hak dari kas negara, maka negara yang diwakili oleh KPK memiliki hak untuk didahulukan dalam pelunasan atau pengembaliannya ketimbang bank sebagai pemegang hak tanggungan, sebagaimana ditentukan dalam Pasal 1137 KUHPerdata, baik sebelum maupun sesudah hak tanggungan lahir.

Bila berpegang Putusan Mahkamah Agung No.1731k/pdt/2011 menegaskan bahwa barang yang sudah dijadikan barang kredit, jaminan tanah dan bangunan yang ada diatasnya ada hak tanggungan tidak dapat dikenakan sita, maka bank masih memiliki kedudukan sebagai kreditur yang diutamakan (preference) dalam pelunasan. Tetapi lain halnya jika proses pemasangan Hak Tanggungan belum selesai dilakukan, hal ini bisa menyebabkan bank bukan lagi sebagai kreditur yang diutamakan (preference) atas pelunasan hutang debitur. Hal ini terjadi jika perjanjian kredit belum bisa langsung diikuti dengan penandatangan APHT dan pendaftarannya ke kantor pertanahan. Kondisi ini kerap terjadi terutama dalam proses pemberian Kredit Pemilikan Rumah (KPR) dimana dibutuhkan proses peralihan hak dengan cara Akta Jual Beli ( AJB ) dan balik nama sertifikat dari nama pihak penjual ke atas nama debitur, atas sertifikat tersebut tidak bisa dibebankan secara langsung yang artinya penandatangan Akta Pemberian Hak Tanggungan tidak bisa langsung dilakukan.

Hak tanggungan baru bisa dibebankan kembali atas jaminan ini apabila sertifikat hak atas tanah tersebut telah selesai diproses dan menjadi atas nama debitor. Pengikatan jaminan atas agunan yang diserahkan tersebut hanya dilakukan dengan pembuatan Surat Kuasa Membebankan Hak Tanggungan (SKMHT). Hal ini disebutkan sesuai Ketentuan pasal 15 ayat (3) dan (4) Undang - Undang No.4 Tahun 1996 Tentang Hak Tanggungan. Pada ayat (3) Surat Kuasa Membebankan Hak Tanggungan atas tanah yang sudah terdaftar wajib disertai dengan pembuatan Akta Pemberian Hak Tanggungan paling lambat satu bulan sesudah diberikan. Pada ayat (4) Surat kuasa membebankan Hak Tanggungan hak atas tanah yang belum terdaftar wajib diikuti dengan pembuatan Akta Pemberian Hak Tanggungan paling lambat tiga bulan sesudah diberikan.

Atas kondisi tersebut apabila dalam jangka waktu yang sudah ditentukan sertifikat yang sudah dibalik nama ke nama debitur belum juga selesai maka SKMHT tersebut akan menjadi gugur atau batal demi hukum dan tidak bisa digunakan untuk pembuatan Akta Pemberian Hak Tanggungan (APHT) atas objek jaminan ini, sedangkan penyelesaian sertifikat untuk tanah yang masih dalam proses balik nama sering kali memakan waktu lebih dari tiga bulan. Untuk itu pihak notaris/Pejabat Pembuat Akta Tanah (PPAT) melakukan perpanjangan SKMHT dengan menghadirkan kembali debitur atau pemilik jaminan untuk mendatangani SKMHT yang baru. Hal ini bisa menyebabkan bank bukan lagi sebagai kreditur yang diutamakan (preference) atas pelunasan hutang debitur jika timbul penyitaan jaminan oleh KPK, otomatis kedudukan jaminan bank atas hak atas tanah dan bangunan milik debitur menjadi lemah. 
Perlindungan Hukum Bagi Bank Atas Jaminan Hak Atas Tanah Milik Debitur yang Disita KPK

Dalam hal terjadinya penyitaan yang menjadi hak bank atas terlunasinya dana yang dipinjamkan pada debitur dapat menimbulkan pertentangan antara kepentingan bank dan kepentingan negara. Pada dasarnya perlu ada perlindungan hukum kepada kreditur dalam hal ini bank selaku pemegang hak tanggungan. Hal tersebut sesuai dengan Yurisprudensi dalam Putusan Mahkamah Agung RI Nomor 1731K/ Pdt/2011 tanggal 14 Desember 2011 ditegaskan bahwa obyek jaminan tanah dan bangunan yang ada di atasnya kredit yang telah dibebani hak tanggungan yang telah diterbitkan Sertifikat Hak Tanggungan harus mendapat perlindungan hukum. Bentuk perlindungan hukum yang diberikan oleh negara pada pemegang Hak Tanggungan, merujuk pada Putusan Mahkamah Agung Nomor 1731K/Pdt/2011, dapat disimpulkan bahwa sita pidana terhadap benda yang di dalamnya terdapat hak tanggungan tidak serta merta menghilangkan kedudukan pemegang hak tanggungan sebagai pihak yang memiliki hak terhadap hak tanggungan tersebut yang. Sekaligus menjawab pertanyaan bahwa jaminan tersebut tetap ada dan tidak hilang dan tanggung jawab untuk melunasi hak tanggungan tersebut masih berada pada debitur. Jika debitur tidak mampu untuk melunasi utangnya maka penerima hak tanggungan berhak untuk menjual objek hak tanggungan dan mendapatkan pelunasan terlebih dahulu.

Melihat ketentuan dalam Pasal 18 UU No.31 Tahun 1999 tentang Pemberantasan Tindak Pidana Korupsi, jelas terlihat bahwa perampasan barang tidak bergerak (dalam hal ini tanah) yang diperoleh dari tindak pidana korupsi sangat mungkin untuk dilakukan. Terlebih KPK memiliki kewenangan yang lebih luas dalam hal penyitaan jika dilihat pada pasal 47 ayat (1) UU No.30 tahun 2002 tentang KPK menyebutkan, atas dasar dugaan yang kuat adanya bukti permulaan yang cukup, penyidik dapat melakukan penyitaan tanpa izin ketua pengadilan negeri berkaitan dengan tugas penyidikannya.

Dengan adanya penyitaan yang dilakukan oleh KPK terhadap harta kekayaan debitur termasuk harta yang dijadikan jaminan tanah dan bangunan yang ada diatasnya di bank maka hal tersebut dapat menimbulkan kerugian pada pihak bank selaku pemegang hak tanggungan. Yang sering menjadi masalah adalah ketika proses penyitaan itu sendiri tidak memiliki kepastian jangka waktu sampai kapan penyitaan itu dilakukan, hingga sampai adanya putusan hakim yang berkekuatan hukum tetap atas perkara tindak pidana korupsi tersebut. Sering kali proses pengadilan harus ditempuh dengan waktu yang lama dan berlarut - larut, sehingga bank hanya bisa menunggu tentang kepastian atas status objek hak tanggungannya yang disita tersebut, untuk sementara waktu pihak bank tidak dapat melakukan eksekusi terhadap objek hak tanggungan tersebut hingga perkara tersebut telah memperoleh kekuatan hukum yang tetap (inkracht).

Perlindungan hukum bagi bank untuk mengatasi jaminan hak atas tanah milik debitur baik yang sebelum maupun yang sudah terpasang Hak Tanggungan yang disita oleh KPK dapat menggunakan perlindungan hukum preventif dan represif(Hadjon, 2007). Perlindungan hukum preventif yaitu mengajukan keberatan terhadap putusan pengadilan yang telah melakukan penyitaan terhadap objek jaminan hak tanggungan tersebut (Hadjon, 2007). Perlindungan hukum represif adalah dengan mengajukan gugatan perdata (melalui jalur litigasi) terhadap harta kekayaan lain milik debitur. Jika sudah timbul penjatuhan hukuman serta sudah adanya putusan pengadilan yang berkekuatan hukum tetap (incraht) dimana objek jaminan itu yang tadinya disita menjadi dirampas oleh Negara maka bank bisa Melakukan gugatan perlawanan (derden verzet) terhadap putusan pengadilan tersebut.

Walaupun belum ada sengketa yang muncul antara bank dan kejaksaan/KPK, tetapi tidak menutup kemungkinan bahwa bisa saja dikemudian hari terjadi sengketa antara bank dan kejaksaan / KPK. Atas hal ini jaksa selaku eksekutor berhak melakukan penyitaan sepanjang dapat dibuktikan itu adalah hasil dari kejahatan. Namun, pemegang jaminan tanah dan bangunan yang ada diatasnya memiliki preferen atau dengan kata lain kedudukannya diutamakan. Jika barang yang disita tersebut sudah dieksekusi, maka kreditur pemegang tanggunganlah yang memiliki hak lebih dulu menerima pelunasan. Jika ada sisanya baru dikasihkan ke Negara.

Hak tanggungan akan hapus atau hilang dalam hal terpenuhinya hal-hal sebagai berikut: 
(1) hapusnya utang, (2) dilepaskan hak tanggungan, (3) pembersihan hak tanggungan atas penetapan peringkat oleh pengadilan negeri, (4) hapusnya hak atas tanah yang dibebani hak tanggungan. Berdasarkan hal tersebut, sita atas barang hasil korupsi bukan merupakan salah satu penyebab hapusnya hak jaminan tanah dan bangunan yang ada diatasnya baik hak tanggungan, yang berarti hak kreditur atas pemegang hak tanggungan tersebut tidaklah hapus dan tetaplah ada terhadap barang jaminan tanah dan bangunan yang ada diatasnya.

Dalam melindungi kepentingan pihak ketiga (dalam hal ini bank), UU Nomor 31 tahun 1999 mengatur secara spesifik tentang perlindungan pihak ketiga (dalam konstruksi kasus di atas adalah kreditur) dalam Pasal 19 UU Tipikor terlihat bahwa UU Tipikor melindungi kepentingan pihak ketiga yang beritikad baik dan juga memberikan kesempatan kepada pihak ketiga untuk mengajukan keberatan kepada pengadilan dalam jangka waktu dua bulan setelah putusan pengadilan diucapkan.

Barang sitaan sebagai suatu benda dengan jaminan tanah dan bangunan yang ada diatasnya hak tanggungan, maka terhadap benda itu melekatlah kedudukan-kedudukan untuk didahulukan dan keistimewaan yang mana sekalipun benda tersebut disita tidak membuat kreditur kehilangan hak tanggunganya karena hak tanggungan tersebut terus melekat pada objek tersebut kecuali diadakan penghapusan tanggungan sebagaiman diatur dalam Pasal 18 UU HT. Karenanya bank guna melindungi kepentingannya dapat melakukan upaya hukum.

\section{SIMPULAN}

Bank berada pada posisi yang terdampak kerugian selaku kreditur apabila jaminan bank yang disita KPK belum terpasang hak tanggungan karena bank belum memiliki hak preference. Kedudukan jaminan bank yang sudah terpasang Hak Tanggungan,bank sebagai kreditur tetap memiliki hak preference. Perlindungan hukum bagi bank untuk mengatasi jaminan hak atas tanah milik debitur baik yang sebelum maupun yang sudah terpasang Hak Tanggungan yang disita oleh KPK dapat menggunakan perlindungan hukum preventif dan represif. Jika sudah timbul penjatuhan hukuman serta sudah adanya putusan pengadilan yang berkekuatan hukum tetap (incraht) dimana objek jaminan itu yang tadinya disita menjadi dirampas oleh negara maka bank bisa belakukan gugatan perlawanan (derden verzet) terhadap putusan pengadilan tersebut.

\section{DAFTAR RUJUKAN}

Abdullah, J. (2014). Tugas dan wewenang lembagalembaga penanganan tindak pidana korupsi di indonesia. YUDISIA, 5(1), 103-122.

Arifuddin, Widhiyanti, H. N., \& Susilo, H. (2017). Implikasi Yuridis Terhadap Pejabat Pembuat Akta Tanah Penerima Kuasa Menyetor Uang Pajak Penghasilan /. JIPPK, 2(1), 18-25.

Choiriyah. (2019). Hukum Perbankan dan Perasuransian Indonesia. Jurnal Sosial \& Budaya Syar-I, 6(3), 265-280. https://doi. org/10.15408/sjsbs.v6i3.11532

Hadjon, P. M. (2007). Perlindungan Hukum Bagi Rakyat Indonesia. Jakarta: PT. Bina Ilmu.

Kasmir. (2002). Dasar-Dasar Perbankan. PT.Raja Grafindo Persada.

Marzuki, P. M. (2011). Penelitian Hukum. Jakarta: Kencana Prenada Media Group.

Rahmi, Z. A., \& Sjafi'i, R. I. R. (1991). Kewajiban Pejabat Pembuat Akta Tanah dalam Melaporkan Adanya Transaksi Keuangan Mencurigakan Terkait Tindak Pidana Pencucian Uang Oleh Klien. JIPPK, 4(1), 197-206.

Rosyad, A. (2014). Barang Bukti Hasil Korupsi. Jurnal Pembaharuan Hukum, I(2), 144-151.

Suhartati. (2014). Reimplementasi hukum pidana korupsi dalam aspek kepemilikan hak atas tanah. Jurnal Hukum Prioris, 4(1), 1-14.

Tatuil, G. S. H. (2013). Penyelesaian Sengketa Atas Kewenangan Penyidikan Kpk Dan Polisi Dalam Menangani Kasus Korupsi. Lex et Societatis, I(3), 138-148.

Valayvi, Y. K. (2016). Perjanjian Kredit Di Lembaga Keuangan Perbankan Berdasarkan Undang Undang Nomor 4 Tahun 1996 Tentang Hak Tanggungan. Privat Law, IV(2), 142-151.

Wiraatmaja, A. Z., Silviana, A., \& Sukirno. (2016). Akibat Hukum Pinjam Meminjam Sertipikat Hak Atas Tanah Untuk Dijadikan Jaminan Utang (Studi Kasus Putusan MA Nomor:2091.K.PDT.2014). DIPONEGORO LAW JOURNAL, 5(3), 1-8. 